\title{
Pengaruh Perlakuan Akuntansi Aktiva Tetap Terhadap Kewajaran Pelaporan Keuangan Pada CV. Sinar Krida Marisa
}

\section{Novaliastuti Masiaga}

Prodi Akuntansi, Fakultas Ekonomi, Universitas Gorontalo Email: novamasiaga01@gmail.com

Abstract
This study aims to determine how much influence the
accounting treatment of fixed assets to the fairness of the financial
reporting on the CV. Activities of Marisa beam either simultaneously
(together) or partially (on their own). Data collection method used in
this research is observation, documentation, questionnaires and
interviews, while the basic information gathering that is through a list
of questions that tested through validity and reliability test every item
questions in the questionnaire. The analytical method used is by using
multiple regression formula, Person Product Moment Correlation, test
statistics To see the relation variable X with variable Y is Partial, and
Test Statistic F to see the relationships variables X and Y
simultaneously.
The object of this research is the accounting treatment of fixed
assets and fairness of financial reporting, research conducted
locations located Cv. Activities of Marisa rays. The first hypothesis
testing results show that the accounting treatment of fixed assets have
a significant effect, amounted to 0.614 or $61.4 \%$, while $38.6 \%$ is
determined by other variables not examined. The second hypothesis
testing results in partial accounting treatment of fixed assets include
valuation of fixed assets (X1) has a very strong relationship, significant
and not the direction of -0.096 or - 96\% and Partially accounting
treatment of fixed assets includes the cost (X2) have a relationship
strong, significant and direction of O.O767 or 76.7\%.
Keywords: Accounting Treatment Of Fixed Assets And The Fairness Of
Financial Reporting

\section{PENDAHULUAN}

Mempertahankan dan mengembangkan perusahaan tidaklah mudah. Banyak faktor penting yang harus diperhatikan untuk menjalankan perusahaan dengan baik, antara lain faktor organisasi, personalia, dan lain-lain. Kelangsungan hidup dan keberhasilan perusahaan akan ditentukan oleh kecepatan reaksi dan ketepatan strategi yang diambil oleh para pimpinan 
perusahaan serta dukungan dari segenap anggota organisasi. Pertumbuhan atau perkembangan suatu perusahaan seringkali berhubungan dengan pihakpihak lain yang berkepentingan dengan perusahaan, diantaranya pemberi kredit. Dengan demikian dengan semakin berkembangnya perusahaan peranan akuntansi menjadi semakin penting.

Perusahaan pada umumnya tidak mengakui keharusan dalam menurunkan nilai aktiva tetap yang dipakai dalam perusahaan, dengan cara mengadakan penyusutan terhadap aktiva tetap itu sendiri. Pengeluaran aktiva tetap dalam jumlah yang tidak material dibebankan sebagai biaya, tetapi apabila nilai pengeluarannya material harus dikapitalisasi ke aktiva tetap atau menambah nilai akitva tetap. Namun seringkali di Perusahaan Pengeluaran yang berhubungan dengan aktiva tetap ini dicatat sebagai biaya pemeliharaan dan dibebankan sebagai biaya operasional pada perhitungan laba rugi pada saat terjadinya pengeluaran tanpa memandang nilai material yang dikeluarkan. Sehingga laporan yang disajikan oleh perusahaan tidak wajar karena tidak sesuai dengan Pernyataan Standar Akuntansi Keuangan. Pengeluaran mengenai penggunaan aktiva tetap perusahaan yang ditampung dalam rekening " Biaya Pemeliharaan" tanpa memandang sifat dan pengaruhnya pada aktiva tetap yang bersangkutan. Berdasarkan uraian latar belakang di atas, maka peneliti merumuskan permasalahan dan tujuan untuk mengetahui:

1. Bagaimana pengaruh perlakuan akuntansi aktiva tetap yang yang terdiri atas penilaian aktiva tetap (X1) dan Harga Perolehan (X2) secara parsial terhadap kewajaran Pelaporan keuangan pada CV. Sinar Krida Marisa?

2. Bagaimana pengaruh perlakuan akuntansi aktiva tetap yang yang terdiri dari penilaian aktiva tetap (X1) dan Harga Perolehan (X2) secara Simultan terhadap kewajaran Pelaporan keuangan pada CV. Sinar Krida Marisa?

\section{LANDASAN TEORI DAN HIPOTESIS}

\subsection{Landasan Teori}

Aktiva tetap adalah aktiva yang tidak lancar yang diperoleh untuk digunakan dalam operasi perusahaan yang memiliki manfaat lebih dari satu periode akuntansi serta tidak untuk diperjual belikan dalam operasi normal perusahaan. aktiva tetap menurut Mulyadi (2001 :34), "Aktiva tetap adalah kekayaan perusahaan yang memiliki wujud, mempunyai manfaat ekonomis lebih dari satu tahun, dan diperoleh perusahaan untuk melaksanakan kegiatan perusahaan, bukan untuk dijual kembali".

Ikatan Akuntan Indonesia (2004: 58) berpendapat bahwa yang dinyatakan dengan "Aktiva tetap adalah aktiva tetap berwujud yang diperoleh dengan membangun lebih dahulu, yang digunakan dalam operasi perusahaan, tidak dimaksudkan untuk dijual dalam rangka kegiatan normal perusahaan, dan mempunyai manfaat lebih dari satu tahun".

Prinsip Penilaian Aktiva Tetap berkaitan dengan penentuan nilai pertukaran dari aktiva tersebut. Ada dua jenis pertukaran yaitu, nilai keluaran dan nilai masukan. Nilai keluaran adalah: aliran dana yang diperkirakan akan diterima perusahaan dimana uang akan datang sesuai dengan harga pertukaran. Sedangkan nilai masukan menunjukan jumlah rupiah yang harus dikeluarkan perusahaan untuk memperoleh aktiva yang akan digunakan dalam kegiatan operasi perusahaan. 
Pengalokasian harga perolehan disebut dengan beban depresiasi".Menurut Soemarso (2000:154), “Adapun yang dimaksud dengan beban depresiasi atau biaya depresiasi adalah biaya yang timbul karena pemakaian aktiva tetap berwujud". Pengalokasian ini dinamakan penyusutan. Untuk menetapkan besarnya nilai penyusutan perusahaan harus memiliki suatu perlakuan akuntansi atas penyusutan aktiva tetap yang memperlihatkan harga perolehan, nilai sisa, taksiran umur kegunaan serta metode perhitungan atas aktiva yang dimiliki".

Penyusutan adalah sebagian dari harga perolehan aktiva tetap yang secara sistematis dialokasikan menjadi biaya pada setiap periode akuntansi. Dari definisi diatas, jelas menunjukkan bahwa penyusutan bukanlah merupakan suatu proses penilaian aktiva atau prosedur pengumpulan dana untuk mengganti aktiva. melainkan merupakan suatu metode untuk mengalokasikan harga perolehan aktiva tetap ke periode-periode akuntansi berikutnya. Penyusutan yang biasa diistilahkan sebagai Depresiasi digunakan untuk menunjukkan alokasi harga perolehan aktiva tetap berwujud yang dapat diganti, seperti mesin. peralatan-peralatan dan lain-lain. Penyusutan merupakan pengakuan adanya penurunan nilai aktiva tetap berwujud.

Aktiva tetap perusahaan disajikan dalam laporan keuangan pada komponen neraca dan berada pada sisi debit neraca. Menurut Sofyan Safri harahap (2002 : 123), bentuk penyajian aktiva tetap di dalam neraca yang umumnya sering digunkanan oleh perusahaan adalah :

1. Neraca yang hanya mencantumkan nilai buku saja atau nilai cost aktiva tetap masing-masing dan kemudian dikurangi akumulasi penyusutan secara global,

2. Informasi yang lebih lanjut dapat dibuat dalam catatan atas laporan keuangan. Di sini dapat dibuat nilai cost masing-masing dan akumulasi penyusutan masing-masing,

3. Informasi yang lebih lanjut lengkap dapat dilihat melalui lampiran daftar aktiva tetap".

Dalam hal ini standar yang mengatur tentang asset tetap adalah PSAK No.16 yang mempunyai pengertian sebagai berikut: Menurut Pernyataan Standar Akuntansi Keuangan (revisi 2007) pengertian PSAK No. 16 adalah sebagai berikut:

"PSAK No. 16 bertujuan untuk mengatur perlakuan akuntansi asset tetap, agar pengguna laporan keuangan dapat memahami informasi mengenai investasi entitas diaset tetap, dan perubahan dalam investasi." (2007:16:1)

\subsection{Hipotesis}

Berdasarkan masalah pokok diatas penulis merumuskan hipotesis kerja yang merupakan jawaban sementara sebagai berikut :

1. Perlakuan akuntansi aktiva tetap yang meliputi penilaian aktiva tetap (X1) dan harga perolehan (X2) secara parsial berpengaruh Positif Terhadap kewajaran Pelaporan keuangan.

2. Perlakuan akuntansi aktiva tetap yang meliputi penilaian aktiva tetap (X1) dan harga perolehan (X2) secara Simultan berpengaruh Positif Terhadap kewajaran Pelaporan keuangan. 


\section{METODE PENELITIAN}

Berdasarkan latar yang di uraikan sebelumnya, maka yang menjadi objek dalam penelitian ini adalah perlakuan Akuntansi Aktiva Tetap sebagai (variabel$\mathrm{X}$ ) dan kewajaran pelaporan keuangan sebagai (variabel- Y). Jenis penelitian yang digunakan dalam penelitian ini adalah penelitian deskriptif. Data penelitiannya terdiri dari: data primer yaitu data yang diperoleh dari daftar pertanyaan yang dibagikan kepada karyawan yang ada pada Cv. Sinar Krida Marisa dan data sekunder yaitu data yang diperoleh berupa informasi-informasi tertulis yang berhubungan dengan penelitian ini, yang mendukung data primer seperti laporan keuangan yang terdiri atas neraca dan laporan laba rugi.

Analisis yang dipakai adalah analisis regresi linier berganda (Multiple Linier Regression Analysis). Sebelum dilakukan pengujian hipotesis yaitu analisis regresi linier berganda terlebih dahulu dilakukan uji kualitas data, uji asumsi klasik. Pengolahan data menggunakan software SPSS (Statistical Package for Social Science).

Wijaya (2012:104) mengemukakan bahwa regresi linier berganda digunakan untuk menguji pengaruh lebih dari saru variabel independen terhadap variabel dependen dengan rumus sebagai berikut :

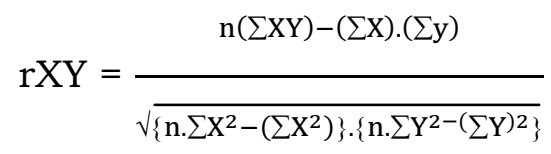

Dimana:

$\mathrm{r}=$ koefisien korelasi

$\mathrm{X}=$ variabel bebas

$\mathrm{Y}=$ variabel terikat

$\mathrm{n}$ = Banyaknya Sampel

\section{HASIL DAN PEMBAHASAN}

\subsection{Hasil Penelitian}

\subsubsection{Gambaran Umum penelitian}

$\mathrm{Cv}$ sinar krida merupakan Dealer Resmi Honda yang menawarkan jenis sepeda motor . yang mana Honda dengan salah satu teknologinya PGM-FI menjadi pelopor Sepeda Motor Injeksi Irit Harga Terbaik. PT Astra Honda Motor (AHM) adalah pelopor industri sepeda motor di Indonesia. Berdiri pada 11 Juni 1971 dengan nama PT Federal Motor, yang sahamnya mayoritas dimiliki oleh PT Astra International. PT Federal Motor pada waktu itu hanya melakukan perakitan saja, sedangkan untuk spare part diimpor langsung dari Jepang dalam bentuk CKD (Completely Knock Down).

\subsubsection{Metode Pengujian Data}

Dalam suatu penelitian kesahihan (Validitas) dan kehandalan (Reliabilitas) suatu hasil penelitian tergantung pada alat pengukur (Instrumen) yang digunakan dan data yang diperoleh. Untuk itu perlu dilakukan pengujian yaitu tes kesasihan (test of validity) dan tes kehandalan (test of realibility)

Jumlah item pernyataan yang akan diberikan kepada responden berjumlah 17 item pernyataan yang terdiri dari 5 (Lima) item pernyataan untuk 
Sub Variabel penilaian aktiva tetap (X1), dan 5 pernyataan untuk sub variabel harga perolehan (X2), serta 7 item pernyataan mengenai kewajaran pelaporan keuangan $(\mathrm{Y})$.

Daftar pernyataan yang berjumlah 17 item telah diuji validitasnya, sehingga demikian pengujian dapat dilanjutkan. Hasil pengujian validitas yang dilakukan terhadap item-item pernyataan dari setiap variabel penelitian ini dapat diuraikan sebagai berikut:

\subsubsection{Hasil Uji Validitas}

Hasil pengujian validitas menunjukkan bahwa item-item yang ada pada Sub variabel penilaian aktiva tetap (X1) sebanyak 5 (lima) pernyataan dan sub variabel harga perolehan (X2) sebanyak 5 (Lima) pertanyaan serta variabel $\mathrm{Y}$ sebanyak 7 (Tujuh ) Uji validitas dilakukan dengan cara menghitung korelasi antara masing-masing daftar pertanyaan dengan skor totalnya.

\subsubsection{Hasil Uji Reliabilitas}

Teknik yang digunakan dalam uji realibilitas adalah teknik belah dua (Split Half Method) teknik ini digunakan dengan memperoleh dua masingmasing item pertanyaan menjadi ganjil dan item pertanyaan genap,kemudian masing-masing belahan dijumlahkan, sehingga menghasilkan dua skor total untuk masing-masing kelompok item pertanyaan. Skor total belahan pertama dan skor total belahan kedua dicari korelasinya dengan menggunakan rumus Korelasi rank sperman, kemudian angka tersebut disesuaikan untuk mendapatkan angka reliabilitas keseluruhannya. Angka reliabilitas (ri) untuk item pertanyaan mengenai variabel penelitian semuanya lebih besar dari 0.60. maka dapat disimpulkan bahwa semua pertanyaan untuk semua variabel dikatakan reliabel.

\subsubsection{Analisis Deskriptif Hasil Penelitian}

Setiap indikator dari variabel akan dilakukan pendeskripsian langkah awal atau untuk mendeskripsikan setiap indikator adalah membuat tabel kategori atau skala penilaian untuk masing-masing ute pertanyaan. Selanjutnya dapat dibuatkan skala penilaian untuk masing-masing item pertanyaan dengan terlebih dahulu menghitung rentang skala. adapun rentangnya dapat dihitung sebagai berikut:

Bobot terendah $\mathrm{x}$ item $\mathrm{x}$ jumlah responden $=1 \times 1 \times 7=7$

Bobot tertinggi $\mathrm{x}$ item $\mathrm{x}$ jumlah responden $=5 \mathrm{x} 1 \mathrm{x} 7=35$

Rentang skalanya yaitu :

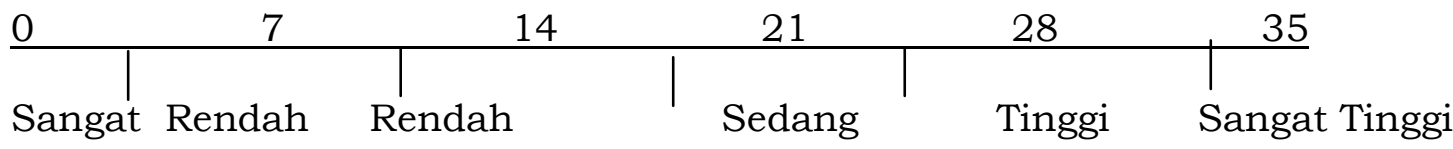

Adapun deskripsi jawaban responden terhadap masing-masing indikator pada pada setiap variabel adalah :

\subsubsection{Penilaian aktiva tetap(X1)}

Berdasarkan hasil tabulasi data diperoleh nilai masing-masing indikator dari variabel Penilaian aktiva tetap (X1) menurut tinjauan responden berdasarkan tabel 4.4 dapat dijelaskan sebagai berikut : 
Tabel 4.1.4 Nilai (Skor) Variabel Penilaian aktiva tetap (X1)

\begin{tabular}{|c|l|l|l|l|l|l|l|l|l|l|}
\hline \multirow{2}{*}{ Bobot } & Tanggapan & \multicolumn{3}{|c|}{ Item 1 } & \multicolumn{3}{c|}{ Item 2 } & \multicolumn{3}{c|}{ Item 3 } \\
\cline { 3 - 12 } & Responden & $\mathbf{N}$ & Skor & $\mathbf{\%}$ & $\mathbf{N}$ & Skor & \% & $\mathbf{N}$ & Skor & \% \\
\hline $\mathbf{5}$ & Selalu & 0 & 0 & 0 & 3 & 15 & 42,85 & 3 & 15 & 42,85 \\
\hline $\mathbf{4}$ & Sering & 3 & 12 & 42,85 & 3 & 12 & 42,85 & 2 & 8 & 28,57 \\
\hline $\mathbf{3}$ & $\begin{array}{l}\text { Kadang- } \\
\text { kadang }\end{array}$ & 4 & 12 & 57,14 & 1 & 3 & 14,28 & 1 & 3 & 14,28 \\
\hline $\mathbf{2}$ & Jarang & 0 & 0 & 0 & 0 & 0 & 0 & 0 & 0 & 0 \\
\hline $\mathbf{1}$ & $\begin{array}{l}\text { Tidak } \\
\text { pernah }\end{array}$ & $\mathbf{0}$ & $\mathbf{0}$ & $\mathbf{0}$ & $\mathbf{0}$ & $\mathbf{0}$ & $\mathbf{0}$ & $\mathbf{0}$ & $\mathbf{0}$ & 0 \\
\hline \multicolumn{2}{|l}{ Jumlah } & $\mathbf{7}$ & $\mathbf{2 4}$ & $\mathbf{1 0 0}$ & $\mathbf{7}$ & $\mathbf{3 0}$ & $\mathbf{1 0 0}$ & $\mathbf{7}$ & $\mathbf{2 6}$ & $\mathbf{1 0 0}$ \\
\hline
\end{tabular}

\subsubsection{Harga perolehan (X2)}

Berdasarkan hasil tabulasi data diperoleh nilai masing-masing indikator dari Harga perolehan (X2) menurut tinjauan responden berdasarkan tabel 4.5 dapat dijelaskan sebagai berikut :

Tabel 4.1.5 Nilai (Skor) variabel Harga perolehan (X2)

\begin{tabular}{|c|l|l|l|l|l|l|l|l|l|l|}
\hline \multirow{2}{*}{ Bobot } & Tanggapan & \multicolumn{3}{|c|}{ Item 1 } & \multicolumn{4}{|c|}{ Item 2 } & \multicolumn{3}{|c|}{ Item 3 } \\
\cline { 3 - 11 } & Responden & $\mathbf{N}$ & Skor & $\mathbf{\%}$ & $\mathbf{n}$ & Skor & \% & $\mathbf{N}$ & Skor & \% \\
\hline $\mathbf{5}$ & Selalu & 0 & 0 & 0 & 3 & 15 & 42,85 & 3 & 15 & 42,85 \\
\hline $\mathbf{4}$ & Sering & 3 & 12 & 42,85 & 3 & 12 & 42,85 & 2 & 8 & 28,57 \\
\hline $\mathbf{3}$ & $\begin{array}{l}\text { Kadang- } \\
\text { kadang }\end{array}$ & 4 & 12 & 57,14 & 1 & 3 & 14,28 & 1 & 3 & 14,28 \\
\hline $\mathbf{2}$ & Jarang & 0 & 0 & 0 & 0 & 0 & 0 & 1 & 2 & 14,28 \\
\hline $\mathbf{1}$ & Tidak pernah & 0 & 0 & 0 & 0 & 0 & 0 & 0 & 0 & 0 \\
\hline & Jumlah & $\mathbf{7}$ & $\mathbf{2 4}$ & $\mathbf{1 0 0}$ & $\mathbf{7}$ & $\mathbf{3 0}$ & $\mathbf{1 0 0}$ & $\mathbf{7}$ & $\mathbf{2 8}$ & $\mathbf{1 0 0}$ \\
\hline
\end{tabular}

Berdasarkan penilaian responden pada sub variabel harga perolehan dapat disimpulkan bahwa rata-rata penilaian responden berada pada skor 27,8 termaksud kategori tinggi atau baik.

\subsubsection{Kewajaran Pelaporan Keuangan (Y)}

Berdasarkan hasil tabulasi data diperoleh nilai masing-masing indikator dari variabel Kewajaran pelaporan keuangan $(\mathrm{Y})$ menurut tinjauan responden berdasarkan tabel 4.6 dapat dijelaskan sebagai berikut :

Tabel 4.1.6 Nilai (Skor) Variabel Kewajaran pelaporan keuangan (Y)

\begin{tabular}{|c|l|l|l|l|l|l|l|l|l|l|}
\hline Bobot & \multirow{2}{*}{$\begin{array}{c}\text { Tanggapan } \\
\text { Responden }\end{array}$} & \multicolumn{4}{|c|}{ Item 1 } & \multicolumn{4}{c|}{ Item 2 } & \multicolumn{3}{|c|}{ Item 3 } \\
\cline { 3 - 10 } & Selalu & 4 & 20 & 57,14 & 4 & 20 & 57,14 & 1 & 5 & 14,28 \\
\hline $\mathbf{5}$ & Sering & 3 & 12 & 42,85 & 3 & 12 & 42,85 & 6 & 24 & 85,71 \\
\hline $\mathbf{3}$ & $\begin{array}{l}\text { Kadang- } \\
\text { kadang }\end{array}$ & 0 & 0 & 0 & 0 & 0 & 0 & 0 & 0 & 0 \\
\hline $\mathbf{2}$ & Jarang & 0 & 0 & 0 & 0 & 0 & 0 & 0 & 0 & 0 \\
\hline $\mathbf{1}$ & $\begin{array}{l}\text { Tidak } \\
\text { pernah }\end{array}$ & 0 & 0 & 0 & 0 & 0 & 0 & 0 & 0 & 0 \\
\hline & Jumlah & $\mathbf{7}$ & $\mathbf{3 2}$ & $\mathbf{1 0 0}$ & $\mathbf{7}$ & $\mathbf{3 2}$ & $\mathbf{1 0 0}$ & $\mathbf{7}$ & $\mathbf{2 9}$ & $\mathbf{1 0 0}$ \\
\hline
\end{tabular}




\begin{tabular}{|c|l|l|l|l|l|l|l|l|l|l|l|}
\hline \multirow{2}{*}{ Bobot } & Tanggapan & \multicolumn{4}{|c|}{ Item 4 } & \multicolumn{4}{c|}{ Item 5 } & \multicolumn{3}{c|}{ Item 6 } \\
\cline { 3 - 11 } & Responden & $\mathbf{N}$ & Skor & \% & N & Skor & \% & n & Skor & \% \\
\hline $\mathbf{5}$ & Selalu & 2 & 10 & 28,57 & 3 & 15 & 42,85 & 5 & 25 & 71,42 \\
\hline $\mathbf{4}$ & Sering & 4 & 16 & 57,14 & 4 & 16 & 57,14 & 1 & 4 & 14,28 \\
\hline $\mathbf{3}$ & $\begin{array}{l}\text { Kadang- } \\
\text { kadang }\end{array}$ & 1 & 3 & 14,28 & 0 & 0 & 0 & 1 & 3 & 14,28 \\
\hline $\mathbf{2}$ & Jarang & 0 & 0 & 0 & 0 & 0 & 0 & 0 & 0 & 0 \\
\hline $\mathbf{1}$ & $\begin{array}{l}\text { Tidak } \\
\text { pernah }\end{array}$ & 0 & 0 & 0 & 0 & 0 & 0 & 0 & 0 & 0 \\
\hline & Jumlah & $\mathbf{7}$ & $\mathbf{2 9}$ & $\mathbf{1 0 0}$ & $\mathbf{7}$ & $\mathbf{3 1}$ & $\mathbf{1 0 0}$ & $\mathbf{7}$ & $\mathbf{3 2}$ & $\mathbf{1 0 0}$ \\
\hline
\end{tabular}

\begin{tabular}{|c|c|c|c|c|}
\hline \multirow[t]{2}{*}{ Bobot } & \multirow{2}{*}{$\begin{array}{l}\text { Tanggapan } \\
\text { Responden }\end{array}$} & \multicolumn{3}{|c|}{ Item 7} \\
\hline & & $\mathbf{N}$ & Skor & $\%$ \\
\hline 5 & Selalu & 2 & 10 & 28,57 \\
\hline 4 & Sering & 5 & 20 & 71,42 \\
\hline 3 & $\begin{array}{l}\text { Kadang- } \\
\text { kadang }\end{array}$ & 0 & 0 & 0 \\
\hline 2 & Jarang & 0 & 0 & 0 \\
\hline 1 & $\begin{array}{l}\text { Tidak } \\
\text { pernah }\end{array}$ & 0 & 0 & 0 \\
\hline \multicolumn{2}{|c|}{ Jumlah } & 7 & 30 & 100 \\
\hline
\end{tabular}

Berdasarkan penilaian responden pada variabel kewajaran pelaporan keuangan dapat disimpulkan bahwa rata-rata penilaian responden berada pada skor 30,71 termaksud kategori sangat baik.

\subsubsection{Analisis Data dan Pengujian Hipotesis}

\subsubsection{Analisis Data}

Analisis regresi linier berganda digunakan untuk mengetahui besarnya pengaruh Variabel Penilaian aktiva tetap secara parsial maupun secara simultan terhadap kewajaran pelaporan keuangan pada CV. Sinar Krida Marisa. Perhitungan statistik dalam analisi regresi linear berganda dapat dilihat pada tabel dibawah ini (Selengkapnya ada pada lampiran)

Tabel 4.1.7.1 Hasil Analisis Regresi linear Berganda Coefficients ${ }^{\mathrm{a}}$

\begin{tabular}{|c|c|c|c|c|c|c|}
\hline \multirow{2}{*}{\multicolumn{2}{|c|}{ Model }} & \multicolumn{2}{|c|}{$\begin{array}{l}\text { Unstandardized } \\
\text { Coefficients }\end{array}$} & \multirow{2}{*}{\begin{tabular}{|c|}
$\begin{array}{c}\text { Standardize } \\
\mathrm{d} \\
\text { Coefficients }\end{array}$ \\
Beta \\
\end{tabular}} & \multirow[b]{2}{*}{$\mathrm{T}$} & \multirow[b]{2}{*}{ Sig. } \\
\hline & & B & Std. Error & & & \\
\hline \multirow[t]{3}{*}{1} & (Constant) & 17.841 & 6.935 & & 2.573 & .062 \\
\hline & $\begin{array}{l}\text { PENILAIAN AKTIVA } \\
\text { TETAP }\end{array}$ & -.052 & .169 & -.096 & -.306 & .775 \\
\hline & $\begin{array}{l}\text { HARGA } \\
\text { PEROLEHAN }\end{array}$ & .715 & .292 & .767 & 2.450 & .070 \\
\hline
\end{tabular}

a. Dependent Variable: KEWAJARAN PELAPORAN KEUANGAN

Model persamaan regresi yang dapat di gambarkan dari hasil tersebut dalam bentuk persamaan regresi standardized adalah sebagai berikut :

$\mathrm{Y}=17,841+(-0,96) \mathrm{X} 1+(0,767) \mathrm{X} 2$ 
Dari persamaan regresi diatas dapat di interpretasikan sebagai berikut :

Konstanta (a) yang didapatkan nilai sebesar 17,841 yang bisa diartikan bahwa perlakuan akuntansi aktiva tetap pada Cv. Sinar Krida Marisa sebesar 17,841. Koefisien regresi untuk penilaian aktiva tetap sebesar -0,96 artinya kontrubusi penilaian aktiva tetap terhadap kewajaran laporan keuangan pada CV. Sinar Krida Marisa adalah sangat kuat, signifikan dan tidak searah, setiap penurunan atau pengurangan penilaian aktiva tetap akan menaikkan kewajaran laporan keuangan sebesar - 96\% atau setiap penaikan atau peningkatan penilaian aktiva tetap akan menurunkan kewajaran pelaporan keuangan sebesar $-96 \%$.

Koefisien regresi untuk harga perolehan sebesar 0,767 artinya kontribusi harga perolehan terhadap kewajaran pelaporan keuangan pada CV. Sinar Krida Marisa adalah kuat, signifikan dan searah, setiap kenaikan atau penambahan harga perolehan akan menaikkan kewajaran laporan keuangan sebesar 76,7\%.

\section{Table 5.8 Koefisien Determinasi}

Model Summaryb

\begin{tabular}{|c|c|c|c|c|c|c|c|c|c|}
\hline \multirow[b]{2}{*}{$\begin{array}{l}\text { Mode } \\
1\end{array}$} & \multirow[b]{2}{*}{$\mathrm{R}$} & \multirow[b]{2}{*}{$\begin{array}{c}\mathrm{R} \\
\text { Square }\end{array}$} & \multirow[b]{2}{*}{$\begin{array}{c}\text { Adjusted R } \\
\text { Square }\end{array}$} & \multirow{2}{*}{$\begin{array}{c}\text { Std. } \\
\text { Error of } \\
\text { the } \\
\text { Estimate }\end{array}$} & \multicolumn{5}{|c|}{ Change Statistics } \\
\hline & & & & & $\begin{array}{l}\text { R Square } \\
\text { Change }\end{array}$ & $\begin{array}{c}\mathrm{F} \\
\text { Change }\end{array}$ & df1 & df2 & $\begin{array}{c}\text { Sig. F } \\
\text { Chan } \\
\text { ge }\end{array}$ \\
\hline 1 & $\begin{array}{r}78 \\
3 \mathrm{a}\end{array}$ & .614 & .421 & 1.220 & .614 & 3.179 & 2 & 4 & .149 \\
\hline
\end{tabular}

a. Predictors: (Constant), HARGA PEROLEHAN, PENILAIAN AKTIVA TETAP

\section{b. Dependent Variable: KEWAJARAN PELAPORAN KEUANGAN}

Dari hasil perhitungan dengan menggunakan program SPSS Versi 17 dapat diketahui bahwa korelasi berganda atau keeratan hubungan variable perlakuan akuntansi aktiva tetap terhadap kewajaran Laporan keuangan CV.Sinar Krida Marisa dari nilai $\mathrm{R}$ yang ada pada hasil pengolahan data yang dilakukan sebesar 0,614. Ini menggambarkan korelasi atau keeratan hubungan antara perlakuan akuntansi aktiva tetap terhadap kewajaran Laporan keuangan CV. Sinar Krida Marisa adalah sebesar 61,4\%

Nilai dari koefisien determinasi atau $R^{2}$ dari hasil pengolahan yang dilakukan didapatkan nilai sebesar 0,614 Hal ini berarti bahwa 61,4 \% pengaruh yang ada terhadap kewajaran laporan keuangan Cv. Sinar Krida Marisa dapat dilihat bahwa variabel perlakuan akuntansi aktiva tetap yang terdiri dari penilaian aktiva tetap dan harga perolehan sebesar 0,386 atau 38,6 $\%$ dipengaruhi oleh variabel lain yang tidak diteliti.

Variabel yang paling berpengaruh terhadap kewajaran laporan keuangan CV. Sinar Krida Marisa adalah Penilaian aktiva tetap (X1) sebesar - 0,96 atau 96 \% dan Harga perolehan (X2) sebesar 0,767 atau 76,7\%

\subsubsection{Pengujian Hipotesis}

\subsubsection{Pengujian Hipotesis Secara Simultan}

Pengujian yang dilakukan dengan menggunakan uji F. Uji F di gunakan untuk menguji ada tidaknya pengaruh variabel-variabel independen terhadap variabel dependen secara simultan (Bersama-sama). Kriteria yang digunakan adalah jika probabilitas atau signifikansi $>0,05$ dan jika $f$ Hitung $<\mathrm{F}$ tabel 
maka Ho diterima jika probabilitas atau signifikansi $<0,05$ dan jika $\mathrm{F}$ hitung $>$ maka Ho ditolak.

Dengan cara membandingkan $\mathrm{F}$ tabel dan $\mathrm{F}$ hitung yang didapatkan dari hasil pengolahan SPSS. Dimana besarnya F tabel sebesar 2,38 dan besarnya F Hitung 3,179 . hasil perbandingan terlihat bahwa besarnya $F$ hitung 3,179 lebih besar dari f tabel 2,38,maka $H_{o}$ ditolak atau $H_{1}$ diterima.berarti perlakuan akuntansi aktiva tetap terhadap kewajaran pelaporan keuangan secara simultan berpengaruh signifikan atau ada hubungan signifikan Pada CV.Sinar Krida Marisa.

\subsubsection{Pengujian Hipotesis Secara Parsial}

Untuk melihat pengaruh secara parsial atau sendiri-sendiri dari sub variabel perlakuan akuntansi aktiva tetapdijelaskan sebagai berikut :

\section{Penilaian aktiva tetap berpengaruh terhadap kewajaran pelaporan} keuangan

Pengujian hipotesis pengaruh penilaian aktiva tetap (X1) terhadap kewajaran pelaporan keuangan dilakukan dengan menggunakan uji t. uji t yaitu suatu uji untuk mengetahui signifikasi pengaruh variebel bebas secara parsial atau individu menerangkan variabel terikat.

Terlihat dari kolom signifikan pada tabel coefisient terdapat nilai 0,775 atau probabilitas jauh di atas 0,05 maka $H_{o}$ diterima dan $H_{1}$ ditolak artinya tidak ada hubungan signifikan antara penilaian aktiva tetap (X1) terhadap kewajaran pelaporan keuangan $(\mathrm{Y})$ pada CV. Sinar Krida Marisa.

\section{Harga perolehan berpengaruh terhadap kewajaran pelaporan keuangan}

Pengujian pengaruh harga perolehan (X2) terhadap kewajaran pelaporan keuangan dilakukan dengan menggunakan uji t. uji t yaitu suatu uji untuk mengetahui signifikasi pengaruh variebel bebas secara parsial atau individu menerangkan variabel terikat.

Terlihat dari kolom signifikan pada tabel coefisient terdapat nilai 0,070 atau probabilitas jauh diatas 0,05 maka $H_{o}$ diterima artinya tidak ada hubungan signifikan antara harga perolehan (X2) terhadap kewajaran pelaporan keuangan (Y) pada CV. Sinar Krida Marisa.

\subsection{Pembahasan}

Berdasarkan hasil pengujian yang diuraikan terdahulu terbukti bahwa perlakuan akuntansi aktiva tetap (X) bahwa koefisien regresi yang terdiri atas penilaian aktiva tetap (X1) berpengaruh sangat kuat, signifikan dan tidak searah dan harga perolehan (X2) berpengaruh kuat, signifikan dan searah.sedangkan hasil uji hipotesis secara simultan berpengaruh signifikan terhadap kewajaran pelaporan keuangan pada CV. Sinar Krida Marisa dan secara parsial perlakuan akuntansi aktiva tetap yang terdiri atas penilaian aktiva tetap (X1) secara parsial berdasakan uji Hipotesis tidak ada hubungan signifikan terhadap kewajaran peloporan keuangan dan sub variabel harga perolehan (X2) berdasarkkan uji hipotesis juga tidak ada hubungan signifikan terhadap kewajaran pelaporan keuangan . untuk lebih jelasnya dapat dilihat uraian berikut ini :

\subsubsection{Pengaruh perlakuan akuntansi aktiva tetap, secara simultan berpengaruh signifikan terhadap kewajaran pelaporan keuangan pada pada CV. Sinar Krida Marisa. \\ Dari hasil pengujian hipotesis maka dapat diketahui besarnya pengaruh} variabel $\mathrm{X}$ dan variabel $\mathrm{Y}$ dari tabel menunjukkan bahwa niali koefisien determinasi total $\left(R_{y x 1 \times 2}^{2}\right)$ sebesar 0,614 atau $61,4 \%$, artinya kewajaran 
pelaporan keuangan pada pada CV. Sinar Krida Marisa di pengaruhi oleh perlakuan akuntansi aktiva tetap berupa penilaian aktiva tetap dan harga perolehan mengacu pada nilai koefisien determinasi $\left(R_{y x 1 x 2}^{2}\right)$ sebesar 0,614 atau $61,4 \%$ maka dapat disimpulkan bahwa variabel $\mathrm{X}$ mempunyai tingkat pengaruh "cukup tinggi " terhadap variabel Y . (Berdasarkan tafsiran dari Guildford, 1956 :145).

Sehubungan dengan nilai koefisien determinasi total $\left(R_{y x 1 \times 2}^{2}\right)$ atau variabel $X$ yang mempengaruhi variabel $Y$ sebesar 61,4\%, maka dapat disimpulkan bahwa terdapat variabel lain yang turut mempengaruhi terhadap variabel Y sebesar 38,6 \% maka dapat disimpulkan bahwa variabel luar tersebut yang tidak diteliti mempunyai tingkat pengaruh ( rendah) terhadap variabel $\mathrm{Y}$ (Berdasarkan tafsiran dari Guildford, 1956 :145).

Besarnya pengaruh perlakuan akuntansi aktiva tetap terhadap kewajaran pelaporan keuangan pada pada CV. Sinar Krida Marisa sebesar 61,4 \%

Dengan demikian bahwa perlakuan akuntansi aktiva tetap berpengaruh cukup tinggi terhadap kewajaran pelaporan keuangan pada pada CV. Sinar Krida Marisa .Dengan demikian penelitian ini terbukti bahwa dengan adanya perlakuan akuntansi aktiva tetap yang tidak baik atau tidak sesuai dengan standar maka akan mempengaruhi kewajaran pelaporan keuangan.

4.2.2 Pengaruh sub variabel penilaian aktiva tetap (X1) bahwa koefisien regresi berpengaruh signifikan, sangat kuat dan tidak searah dan uji hipotesis secara parsial tidak ada hubungan signifikan, terhadap kewajaran pelaporan keuangan pada CV. Sinar Krida Marisa.

Dari hasil koefisien regresi maka dapat diketahui besarnya pengaruh sub variabel penilaian aktiva tetap (X1) terhadap kewajaran pelaporan keuangan (Y) sebesar -0,96 atau - $96 \%$ menunjukkan bahwa dari hasil pengamatan peneliti mengenai perlakuan akuntansi aktiva tetap yang meliputi penilaian aktiva tetap (X1) mempunyai hubungan tidak searah dengan kewajaran pelaporan keuangan.artinya bahwa jika dalam hal penilaian aktiva kurang baik atau tidak sesuai standar akan berdampak pada kewajaran pelaporan keuangan dan berdasarkan uji hipotesis bahwa penilaian aktiva tetap tidak ada hubungan signifikan terhadap kewajaran pelaporan keuangan karena Signifikansi lebih besar dari 0,05 dimana 0,0775 > 0,05.

4.2.3 Pengaruh Sub Variabel harga perolehan (X2) bahwa koefisien regresi berpengaruh kuat,signifikan dan searah dan uji hipotesis secara parsial berpengaruh tidak signifikan terhadap kewajaran pelaporan keuangan pada CV. Sinar Krida Marisa.

Dari hasil koefisien regresi maka dapat diketahui besarnya pengaruh sub variabel harga perolehan (X2) terhadap kewajaran pelaporan keuangan (Y) sebesar 0,767 atau 76,7 \% menunjukkan bahwa dari hasil pengamatan peneliti mengenai penilaian aktiva tetap (X2) mempunyai hubungan kuat, signifikan dan searah artinya bahwa jika dalam metode yang digunakan dalam harga perolehan baik maka akan baik juga terhadap kewajaran pelaporan keuangan, dan berdasarkan uji hipotesis menunjukkan bahwa tidak ada hubungan yang signifikan antara harga perolehan terhadap kewajaran pelaporan keuangan karena signifikansi lebih besar dari 0,05 dimana 0,070 >0,05. 


\section{KESIMPULAN}

Berdasarkan pembahasan hasil penelitian maka dapat disimpulkan dan sebagai berikut :

1. Secara simultan perlakuan akuntansi aktiva tetapyang meliputi penilaian aktiva tetapdan harga perolehan terhadap kewajaran pelaporan keuangan pada CV. Sinar Krida sebesar 61,4 \% termaksud kategori Tinggi sedangkan sebesar 38,6 \% ditentukan oleh variabel lain yang tidak diteliti. pengaruhnya termaksud kategori rendah.

2. Secara parsial perlakuan akuntansi aktiva tetap yang meliputi penilaian aktiva tetap(X1) mempunyai hubungan yang tidak searah (Negatif) terhadap kewajaran pelaporan keuangan pada CV. Sinar Krida Marisa sebesar - 0,96 atau - $96 \%$ dan berdasarkan hasil uji hipotesis dinyatakan tidak signifikan karena signifikan diatas 0,05.

3. Secara parsial Perlakuan akuntansi aktiva tetap yang meliputi harga perolehan (X2) mempunyai hubungan yang searah (Positif) terhadap kewajaran pelaporan keuangan pada CV. Sinar Krida Marisa sebesar 0,767 atau 76,7 \% dan berdasarkan hasil uji hipotesis dinyatakan tidak signifikan karena tingkat singnifikan diatas 0,05.

\section{DAFTAR PUSTAKA}

Ahmed Riahi Belkaoui, 2001. Teori Akuntansi, Buku 1, Edisi Keempat, Alih Bahasa: Marwata ddk, Penerbit Salemba Empat, Jakarta.

Ikatan Akuntansi Indonesia. 2004, Standar Akuntansi Keuangan, Salemba Empat, Jakarta.

Munawir S. Drs, 1990. Analisa Laporan Keuangan, Edisi Keempat. Penerbit Liberty,Yogyakarta.

Mulyadi. 2005. Akuntansi Biaya,edisi ke-6. Yogyakarta: STIE YKPN.

Moh.Nazir . 2008 .Metodelogi Penelitian. Penerbit Salemba Empat, Jakarta.

Teguh . 2000. Metode Penelitian Kuantitatif, Kualitatif. PT.Alfabeta. Bandung

Nur Indriantoro. 2002. Metodelogi Penelitian Bisnis. Cetakan Kedua.BPFE. Yogyakarta

Soemarso. 2005. Akuntansi Suatu Pengantar .Buku 1, Edisi Keenam. : PT Rineka. Jakarta

Soemarso. 2000. Akuntansi Suatu Pengantar. Buku 1, Edisi Kedua. : PT Rineka Cipta.Jakarta

Sofyan.2007. Dasar akuntansi . edisi empat: Salemba Empat

Skousen K Fred. 2001. Akuntansi Keuangan Menengah. Edisi Ketiga belas. Buku Satu. Dian Mas Cemerlang, Jakarta

Supriyono. 2000. Akuntansi Biaya, Buku 1, edisi dua. Yogyakarta: BPFE.

Sugiyono. 2007. Metode Penelitian Kuantitatif, Kualitatif, R\&D . Penerbit PT Kiblat Bandung: CV Pustaka Utama. Bandung

Warren, Carl S, James M. Reeve, Philip E. Fess, tanpa tahun, Pengantar Akuntansi, Terjemahan oleh Aria Farahmita, Amanugrahani, dan Taufik H, 2005, Penerbit Salemba Empat, Jakarta. 